\title{
NHÂN MộT TRƯờNG HợP LỒNG RUộT Ở TRẺ SƠ SINH
}

\author{
Dương Thị Thụy, Nguyễn Thị Quỳnh Nga \\ Đại học Y Hà Nội
}

\begin{abstract}
TÓM TẮT
Lồng ruột hiếm gặp ở trẻ sơ sinh, đặc biệt đối với trẻ sinh non cực kỳ hiếm gặp và thường bị nhầm lẫn với viêm ruột hoại tử hoặc xoắn ruột do có các triệu chứng lâm sàng tương đồng dẫn đến việc chẩn đoán bệnh thường chậm trễ. Chúng tôi báo cáo một trường hợp trẻ sơ sinh đủ tháng vào viện do bụng chướng, nôn ra máu và đi ngoài phân máu. Trước phẫu thuật trẻ được chẩn đoán xoắn ruột, sau khi mổ phát hiện nguyên nhân gây ra tình trạng trên do lồng ruột. Do đó, lồng ruột dù hiếm gặp nhưng cân được xem xét để chẩn đoán đối với những trường hợp trẻ sơ sinh có các triệu chứng tiêu hóa.
\end{abstract}

\section{1. ĐĂT VẤN ĐỀ}

Lồng ruột là tình trạng đoạn ruột phía trên chui vào lòng đoạn ruột phía dưới, thường xảy ra ở ruột non và hiếm gặp ở đại tràng. Dưới $1,3 \%$ tổng số trường hợp lồng ruột xảy ra ở trẻ sơ sinh đủ tháng và càng hiếm gặp hơn lồng ruột ở trẻ sơ sinh non tháng [1]. Do tình trạng ít gặp và các triệu chứng lâm sàng không đầy đủ thường dẫn đến nhầm lẫn chẩn đoán với bệnh viêm ruột hoại tử- một bệnh gặp phổ biến hơn trong nhóm tuổi này. Điều này dẫn đến chậm trễ trong quá trình chẩn đoán và điều trị phẫu thuật làm tăng tỷ lệ mắc bệnh và tử vong. Nguyên nhân gây bệnh vẫn còn chưa rõ ràng trong đa số các trường hợp. Chúng tôi xin trình bày một trường hợp sơ sinh đủ tháng 9 ngày tuổi bị lồng ruột được chẩn đoán sau khi đã được phẫu thuật.

\section{BÁO CÁO TRƯờNG HợP}

Trẻ là con thứ hai, 38 tuần sinh thường tại nhà, được cắt rốn bằng kéo cắt giấy không được sát trùng, sau sinh trẻ khóc ngay. 5 ngày tuổi, xuất hiện tình trạng chảy máu và mủ qua rốn, gia đình có điều trị thuốc nam nhưng không đỡ. Trẻ được đưa vào viện tỉnh điều trị với chẩn đoán nhiễm khuẩn huyết. Sau điều trị 1 ngày trẻ xuất hiện dịch dạ dày nhiều máu thẫm, đi ngoài phân lẫn máu, bụng chướng, ăn kém, da tái. Xét nghiệm rối loạn đông máu nặng, chuyển lên Bệnh viện Nhi Trung ương điều trị. Trẻ vào viện trong tình trạng thở gắng sức, da niêm mạc nhợt, bụng chướng, dịch dạ dày và phân có nhiều máu, tiến hành đặt ống nội khí quản, thở máy, chụp Xquang và siêu âm cấp, làm xét nghiệm đánh giá tình trạng nhiễm trùng và rối loạn đông máu.

Xét nghiệm huyết học có tình trạng nhiễm trùng nặng, maker viêm tăng cao, rối loạn đông máu APTT 46,9 s, PT 39\%. Xquang bụng (Hình 1) có hình ảnh dạ dày giãn to, không có mức nước - hơi, không thấy đặc điểm hình ảnh bệnh lý viêm ruột hoại tử. Siêu âm ổ bụng ghi nhận vùng thượng vị có hình ảnh xoáy nước, kèm theo quai ruột phù nề, dịch tự do ổ bụng, dịch trong, dày $7 \mathrm{~mm}$. Kết luận có hình ảnh xoắn trung tràng. 


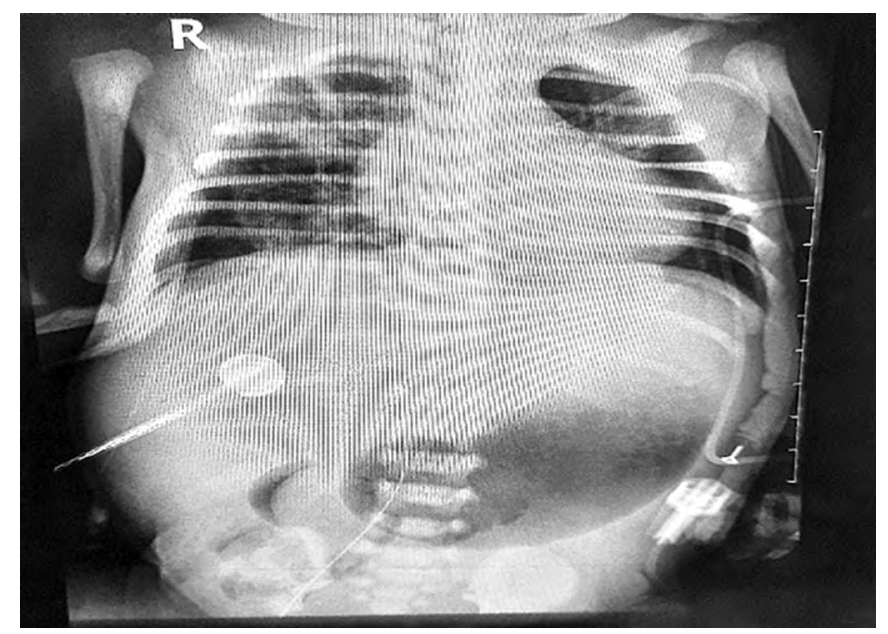

Hình 1. Xquang bụng có hình ảnh dạ dày giãn

Trẻ được chẩn đoán trước phẫu xoắn ruột và có chỉ định mổ cấp cứu. Sau khi mở bụng thấy có dạ dày giãn, thành dạ dày sung huyết có điểm thiếu máu chưa hoại tử trong lòng chứa nhiều máu đen. Quai hỗng tràng đầu tiên từ góc Treitz có nhiều điểm viêm sung huyết thiếu máu chưa hoại tử, có khối lồng cách góc Treitz $20 \mathrm{~cm}$ là nguyên nhân gây tắc ruột. Bác sĩ phẫu thuật đã tiến hành tháo lồng bằng tay thành công, khối lồng lỏng không gây tổn thương ruột. Sau quá trình phẫu thuật trẻ ổn định, tình trạng nhiễm trùng cải thiện.

\section{THẢO LUÂN}

Lồng ruột là nguyên nhân phổ biến gây tắc ruột ở trẻ em, thường cao nhất là từ 4 - 9 tháng tuổi, đỉnh điểm là 5 tháng tuổi, sau đó giảm dần vào khoảng 18 tháng và hay gặp ở trẻ nam nhưng lại hiếm gặp ở trẻ sơ sinh, đặc biệt trẻ sinh non. Nó chỉ chiếm $3 \%$ các trường hợp gây tắc ruột trẻ sơ sinh [2]. Điều này thường dẫn đến chẩn đoán sai ban đầu gây ra sự chậm trễ trong chẩn đoán và điều trị, đặc biệt các triệu chứng của bệnh giống với viêm ruột hoại tử, nhưng xử trí hoàn toàn trái ngược nhau. Trong một số báo cáo chỉ ra rằng thời gian chậm trễ đó là đáng kể trung bình từ 10 - 19 ngày [1], [3]. Điều này làm tăng nguy cơ ruột bị tổn thương. Lồng ruột thường được phát hiện sau khi được phẫu thuật mở bụng [4], [5].
Lồng ruột thường gặp ở ruột non và hiếm gặp ở đại tràng. Trong trường hợp lồng ruột của chúng tôi đã báo cáo, bệnh nhân bị lồng ở đoạn hỗng tràng. Nguyên nhân của lồng ruột thường không được biết rõ ràng, có thể do yếu tố nhiễm trùng, giải phẫu và thay đổi nhu động của ruột. Đối với trẻ sơ sinh, người ta cho rằng các yếu tố nguy cơ chu sinh như suy hô hấp, còn ống động mạch, thiếu oxy, hạ huyết áp dẫn đến giảm tưới máu ruột, rối loạn chức năng có thể dẫn đến lồng ruột [6]. Trong một nghiên cứu của Ueki và cộng sự thực hiện trên 14 trẻ sơ sinh đã đưa ra rằng các nguyên nhân dẫn đến thiếu oxy có thể đóng vai trò quan trọng trong cơ chế của lồng ruột sơ sinh khởi phát muộn [7].

Triệu chứng lồng ruột ban đầu có thể xuất hiện như bụng chướng, ăn không tiêu, nôn và đi ngoài phân có máu. Các triệu chứng này gần giống với viêm ruột hoại tử, một số trường hợp ít gặp có thể sờ thấy một khối ở bụng. Tình trạng bệnh nhân có thể xấu đi khi xuất hiện thủng gây viêm phúc mạc, nhiễm khuẩn huyết.

Không có báo cáo nào về hình ảnh đặc trưng cụ thể của Xquang ở bệnh lồng ruột. Hình ảnh phổ biến nhất có thể gặp là các quai ruột giãn, thỉnh thoảng xuất hiện mức nước - hơi do tắc ruột gây nên. Hình ảnh này trái ngược với trong viêm ruột hoại tử gồm bóng khí ở thành ruột và/ hoặc trong hệ thống tĩnh mạch cửa. Tuy nhiên, 
chỉ khoảng một nửa bệnh nhân có hình ảnh này [8]. Các nghiên cứu gần đây chỉ ra rằng siêu âm có khả năng chẩn đoán sớm lồng ruột ở trẻ sơ sinh, ở mặt cắt ngang thấy được hình ảnh bia đạn với nhiều vòng tròn đồng tâm, còn ở mặt cắt dọc có hình bánh kẹp "sandwich" với các lớp xếp chồng lên nhau. Tuy nhiên không phải trường hợp nào cũng có thể quan sát được hình ảnh điển hình, trong trường hợp của chúng tôi trình bày trên hình ảnh trên siêu âm quan sát được là dấu hiệu xoáy nước hay gặp hơn trong xoắn ruột, gây chẩn đoán nhầm lẫn ban đầu.

Điều trị chủ yếu trong lồng ruột ở trẻ sơ sinh là phẫu thuật. Phương pháp này có vai trò trong chẩn đoán và đánh giá được tình trạng đoạn ruột lồng để quyết định bảo tồn hay cắt đoạn ruột hoại tử hoặc thủng.

\section{KẾT LUÂNN}

Lồng ruột ở trẻ sơ sinh rất hiếm gặp, các triệu chứng của bệnh thường gây khó khăn và nhầm lẫn với viêm ruột hoại tử. Điều này có thể gây trì hoãn trong việc chẩn đoán và làm gia tăng tỷ lệ tử vong của bệnh nhân. Đối với các trường hợp khi chẩn đoán viêm ruột hoại tử mà đáp ứng kém với điều trị thì nên nghi ngờ đến các chẩn đoán khác. Các dấu hiệu của Xquang có thể giúp phân biệt viêm ruột hoại tử và hình ảnh siêu âm bụng có hữu ích trong chẩn đoán lồng ruột sơ sinh. Chẩn đoán và xử trí kịp thời có thể cải thiện tình trạng xấu có thể xảy ra đối với bệnh nhân.

\section{TÀI LIỆ THAM KHẢO}

1. Avansino J.R., Bjerke S., Hendrickson M., et al. (2003). Clinical features and treatment outcome of intussusception in premature neonates. J Pediatr Surg, 38(12), 1818-1821.

2. Wang N.L., Yeh M.L., Chang P.Y., et al. (1998). Prenatal and neonatal intussusception. Pediatr Surg Int, 13(4), 232-236.

3. Mooney D.P., Steinthorsson G., and Shorter N.A. (1996). Perinatal intussusception in premature infants. J Pediatr Surg, 31(5), 695-697.

4. Prakash A., Doshi B., Singh S., et al. (2015). Intussusception in a premature neonate: $\mathrm{A}$ rare and often misdiagnosed clinical entity. Afr J Paediatr Surg AJPS, 12(1), 82.

5. Görgen-Pauly U., Schultz C., Kohl M., et al. (1999). Intussusception in preterm infants: case report and literature review. Eur J Pediatr, 158(10), 830-832.

6. Slam K.D. and Teitelbaum D.H. (2007). Multiple sequential intussusceptions causing bowel obstruction in a preterm neonate. J Pediatr Surg, 42(7), 1279-1281.

7. Ueki I., Nakashima E., Kumagai M., et al. (2004). Intussusception in neonates: Analysis of 14 Japanese patients. J Paediatr Child Health, 40(7), 388-391.

8. Loukas I., Baltogiannis N., Plataras C., et al. (2009). Intussusception in a Premature Neonate: A Rare Often Misdiagnosed Cause of Intestinal Obstruction. Case Rep Med, 2009. 